\title{
Inhibition of Iron-Catalyzed Oxidations by Attainable Uric Acid and Ascorbic Acid Levels: Therapeutic Implications for Alzheimer's Disease and Late Cognitive Impairment
}

\author{
William H. Waugh \\ Department of Physiology, Brody School of Medicine, East Carolina University, Greenville, N.C., USA
}

\section{Key Words}

Brain iron · Longevity $\cdot$ Uric acid · Ascorbic acid •

Alzheimer's disease $\cdot$ Fenton reaction

\begin{abstract}
Background: Alzheimer's disease (AD) has become one of the major health problems of the developed world. Previous studies have shown that oxidant-induced changes occur in cerebral tissue in $A D$ and in late-onset amnestic mild cognitive impairment. The oxidative damage begins early and involves free radical-mediated effects that cause lipid peroxidations and oxidative protein and nucleic acid damages which begin before the cardinal neuropathologic manifestations. Impaired cerebral iron homeostasis and iron accumulation are postulated to be primary and seminal in the pathogenesis. Objective: To demonstrate that the Fenton reaction involving hydrogen peroxide and iron at very low concentrations as has been found in human plasma and cerebrospinal fluid may produce promptly oxidations which may be inhibited by preventive use of uric acid and ascorbic acid as hydrophilic antioxidants. Methods: A photometric study in vitro at physiologic $\mathrm{pH}$ using concentrations of uric acid and ascorbic acid readily attainable in human extracellular fluids. Results: Uric acid levels of 0.5 and $6.0 \mathrm{mg} / \mathrm{dl}$ (below the saturation level for urate precipitation) and ascorbic acid at a level readily attainable in blood plasma inhibited
\end{abstract}

significantly and completely, respectively, oxidations caused by reactions of $20 \mu \mathrm{M}$ concentrations of hydrogen peroxide with free bivalent iron at $9.8 \mu \mathrm{M}$ and at a low hemoglobin level of $12 \mathrm{mg} / \mathrm{dl}$ of saline. Conclusion: Results suggest that supplemental use orally of ascorbic acid combined with use of metabolic precursor to uric acid, like inosine or hypoxanthine, has the potential for preventing or attenuating the progression of $A D$ and amnestic mild cognitive impairment.

Copyright $\odot 2008$ S. Karger AG, Basel

\section{Introduction}

Alzheimer's disease (AD) has become one of the major health problems in the United States and the entire developed world. Because the presence of AD clinically doubles with every 5 years of chronological age after 60 , delaying onset by 5 years would reduce the prevalence by half $[1,2]$. Prevention of mild cognitive decline preceding diagnosable $\mathrm{AD}$ and declines in $\mathrm{AD}$ dementia will probably be most effective when the intervention targets a process closely relevant to the disease pathogenesis [3].

Oxidative stress-mediated damage in cerebral tissue in $\mathrm{AD}$, involving oxidation of nucleic acids, proteins, and lipids, are all prominent in the early stages of AD [4].

\section{KARGER}

Fax +41613061234 E-Mail karger@karger.ch www.karger.com
William H. Waugh, MD, FACP

Department of Physiology, Brody School of Medicine

East Carolina University, 119 Oxford Road

Greenville, NC 27858 (USA)

Tel. +1 252756 5999, Fax + 1252744 3460, E-Mail egwhwaugh@webtv.net 
The oxidative stress changes have been shown to precede the cardinal neuropathologic manifestations of $\mathrm{AD}$ [4]. In addition, recent studies on patients with amnestic mild cognitive impairment (MCI) have shown increased lipid peroxidation and protein, DNA, and RNA oxidative changes in multiple brain regions [5]. These latter studies establish that free radical-mediated oxidative damage is involved as an early event in the neuron damage in $\mathrm{AD}[5]$.

Disruption of cerebral iron homeostasis with iron overloading is a likely primary seminal event in $\mathrm{AD}$ and in late MCI [6]. This theory for the pathogenesis of $\mathrm{AD}$ was first proposed by Goodman [7] in 1953 and is supported strongly by the studies of Connor et al. $[8,9]$ that the cerebral iron-regulatory system is dysfunctional in $\mathrm{AD}$.

There is over-accumulation of iron in the hippocampus, cerebral cortex, and basal nucleus of Meynert $[8,9]$. These affected brain areas are of special interest because they represent centers of memory and thought processes, all lost in the clinical picture of AD.

Brain iron is very toxic in its bivalent form when it reacts with hydrogen peroxide to produce highly reactive hydroxyl free radicals. This reaction between ferrous iron and hydrogen peroxide (which is diffusible) is termed the Fenton reaction. [10]. As soon as hydroxyl radicals are formed, they react with many different organic molecules in their immediate vicinity [10]. Hydroxyl radicals will react very quickly with almost every type of molecule found in living cells, e.g. sugars, amino acids, DNA bases, and organic acids [10]. Notably, iron is reported elevated in the cerebrospinal fluid (CSF) in AD compared to in control other elderly patients [11].

Uric acid is a strong scavenger of free radicals [12]. This end-product of purine metabolism in man is believed to be responsible in part for the longevity of humans because of its antioxidant properties [12]. Uric acid concentrations in serum and brain correlate with the highest maximum lifespan potential in man among mammals, perhaps concomitant with the antioxidant properties of ascorbic acid $[13,14]$.

Uric acid and ascorbic acid are two of the major hydrophilic antioxidants present in human plasma [15] and they may be likely relevant to the initial pathogenesis in $\mathrm{AD}$ and in late-onset MCI. Therefore, the following antioxidant experiments with uric acid and ascorbic acid, iron salt, and free human hemoglobin were performed in saline solutions mimetic of CSF except devoid of possible confounding other organic molecules.

\section{Methods and Materials}

Control and test solutions contained $9.0 \mathrm{mg} / \mathrm{dl}$ of $o$-dianisidine as a potential chromogenic hydrogen donor to be oxidized in saline solution of $140 \mathrm{mM} \mathrm{NaCl}$ and $3.0 \mathrm{~mm}$ phosphate buffer of $\mathrm{Na}_{2} \mathrm{HPO}_{4}-\mathrm{KH}_{2} \mathrm{PO}_{4}, \mathrm{pH} 7.4$, and either $9.8 \mu \mathrm{M}$ of ferrous sulfate or $12 \mathrm{mg} / \mathrm{dl}$ of human hemoglobin. The ferrous sulfate or hemoglobin was added to the solutions shortly before photometric measurements. Hydrogen peroxide at a final level of $20 \mu \mathrm{M}$ was added with vortex mixing for $2-3 \mathrm{~s}$ promptly before timed absorbance measurements in 12-mm diameter tube cuvettes in a Bausch \& Lomb Spectronic 20 colorimeter at $460 \mathrm{~nm}$. This was to detect oxidations of the included $o$-dianisidine as chromogen. The test solutions included uric acid at concentrations of $6.0 \mathrm{mg} / \mathrm{dl}(357$ $\mu \mathrm{M})$ or of $0.5 \mathrm{mg} / \mathrm{dl}(30 \mu \mathrm{M})$ or L-ascorbic acid at level of $1.6 \mathrm{mg} / \mathrm{dl}$. In a few determinations, allantoin at $5.6 \mathrm{mg} / \mathrm{dl}(357 \mu \mathrm{M})$, or L-lysine free base at $0.44 \mathrm{mg} / \mathrm{dl}(30 \mu \mathrm{M})$, or L-arginine free base at 0.52 $\mathrm{mg} / \mathrm{dl}(30 \mu \mathrm{M})$ was included instead as a test solution. Solution incubations and measurements were made at room temperatures of $25-28^{\circ} \mathrm{C}$.

\section{Chemicals}

Employed were $o$-dianisidine dihydrochloride, L-ascorbic acid (cell culture tested), human hemoglobin (lyophilized), allantoin, L-arginine free base (cell culture tested), and L-lysine free base, all obtained from Sigma Chemical Co. (St. Louis, Mo., USA). Uric acid was from Fisher Scientific Co. (Fair Lawn, N.J., USA). Hydrogen peroxide, $3 \%$, was used. Ferrous sulfate $7 \mathrm{H}_{2} \mathrm{O}$ from Mallinckrodt Chemical Works (St. Louis, Mo., USA) and all other chemicals used were of analytical grade. Distilled water was employed.

\section{Statistical Analysis}

Paired Student's two-tailed t tests for mean differences between control data and the data of test solutions were used. Control solutions and test solutions were paired individually and measured concurrently at the same time intervals. Standard errors of means (SEM) are listed. p values $\leq 0.5$ were considered to indicate statistical significant differences.

\section{Results}

Table 1 show the results when uric acid was used at the two listed concentrations to try to reduce the oxidations of dianisidine at the micromolar concentrations of $9.8 \mu \mathrm{M}$ of ferrous sulfate and $20 \mu \mathrm{M}$ of hydrogen peroxide. The control absorbance increases or measured oxidations of dianisidine became quickly maximal within $5 \mathrm{~min}$ at physiological pH of 7.4 (see table 1). At a urate level of 6.0 $\mathrm{mg} / \mathrm{dl}(357 \mu \mathrm{M})$, the inhibition of oxidation averaged 75.3 $\pm 4.8 \%$. At a concentration 12 -fold less or $8.3 \%$ of the higher urate level, i.e. at $0.5 \mathrm{mg} / \mathrm{dl}(30 \mu \mathrm{M})$, the mean inhibition was considerably less at $36.0 \pm 5.3 \%$. At both concentrations of uric acid, the inhibition became mildly less during the next $5 \mathrm{~min}$ of incubation time. 
Table 1. Uric acid inhibition of substrate oxidation induced by micromolar reaction of ferrous sulfate $(9.8 \mu \mathrm{M})$ with hydrogen peroxide at $20 \mu \mathrm{M}$

\begin{tabular}{lrll}
\hline & $\begin{array}{c}\text { Time after } \\
\mathrm{H}_{2} \mathrm{O}_{2}\end{array}$ & $\begin{array}{l}\text { Absorbance in- } \\
\text { crease after } \mathrm{H}_{2} \mathrm{O}_{2}\end{array}$ & $\begin{array}{l}\% \\
\text { inhibition }\end{array}$ \\
\hline Control & $5 \mathrm{~min}$ & $0.049 \pm 0.004$ & \\
& $10 \mathrm{~min}$ & $0.049 \pm 0.004$ & \\
Urate, $6.0 \mathrm{mg} / \mathrm{dl}$ & $5 \mathrm{~min}$ & $0.012 \pm 0.003$ & $75.3 \pm 4.8^{* *}$ \\
$\quad(357 \mu \mathrm{M})$ & $10 \mathrm{~min}$ & $0.014 \pm 0.003$ & $70.9 \pm 4.5^{* *}$ \\
Control & $5 \mathrm{~min}$ & $0.047 \pm 0.008$ & \\
Urate, $0.5 \mathrm{mg} / \mathrm{dl}$ & $10 \mathrm{~min}$ & $0.047 \pm 0.004$ & \\
$\quad 5 \mathrm{~min}$ & $0.030 \pm 0.003$ & $36.0 \pm 5.3^{* *}$ \\
$(30 \mu \mathrm{M})$ & $10 \mathrm{~min}$ & $0.034 \pm 0.017$ & $26.5 \pm 5.5^{*}$ \\
\hline
\end{tabular}

Mixtures of $5.085 \mathrm{ml}$ were incubated at room temperature of $25-28^{\circ} \mathrm{C}$. Values are means $\pm S E M, n=5$. Significance of mean difference in percentage from control value: ${ }^{*} \mathrm{p}<0.01,{ }^{* *} \mathrm{p}<$ 0.001 . Substrate as chromogenic hydrogen donor detected at 460 $\mathrm{nm}$ was $o$-dianisidine at $9 \mathrm{mg} / \mathrm{dl}$ in buffered saline of $140 \mathrm{~mm}$ $\mathrm{NaCl}, \mathrm{Na}_{2} \mathrm{HPO}_{4}-\mathrm{KH}_{2} \mathrm{PO}_{4}$ of $3.0 \mathrm{~mm}$, pH 7.4. Allantoin at $5.6 \mathrm{mg} /$ $\mathrm{dl}(357 \mu \mathrm{M})$ and both L-lysine and L-arginine free base at $0.44 \mathrm{mg} /$ $\mathrm{dl}(30 \mu \mathrm{M})$ and $0.52 \mathrm{mg} / \mathrm{dl}(30 \mu \mathrm{M})$, respectively, failed to decrease the developed absorbance below that of the developed control oxidation in individual experiments.

Table 2. Uric acid inhibition of substrate oxidation induced by human hemoglobin level of $12 \mathrm{mg} / \mathrm{dl}$ in reaction with hydrogen peroxide at $20 \mu \mathrm{M}$

\begin{tabular}{lrll}
\hline & $\begin{array}{c}\text { Time after } \\
\mathrm{H}_{2} \mathrm{O}_{2}\end{array}$ & $\begin{array}{l}\text { Absorbance in- } \\
\text { crease after } \mathrm{H}_{2} \mathrm{O}_{2}\end{array}$ & $\begin{array}{l}\% \\
\text { inhibition }\end{array}$ \\
\hline Control & $5 \mathrm{~min}$ & $0.059 \pm 0.002$ & \\
& $10 \mathrm{~min}$ & $0.084 \pm 0.017$ & \\
Urate, $6.0 \mathrm{mg} / \mathrm{dl}$ & $5 \mathrm{~min}$ & $0.006 \pm 0.002$ & $90.6 \pm 0.90^{* * *}$ \\
$\quad(357 \mu \mathrm{M})$ & $10 \mathrm{~min}$ & $0.016 \pm 0.005$ & $80.3 \pm 3.54^{* *}$ \\
Urate, $0.5 \mathrm{mg} / \mathrm{dl}$ & $5 \mathrm{~min}$ & $0.028 \pm 0.004$ & $50.7 \pm 7.56^{*}$ \\
$(30 \mu \mathrm{M})$ & $10 \mathrm{~min}$ & $0.052 \pm 0.009$ & $38.8 \pm 3.25^{* *}$
\end{tabular}

Mixtures of $5.060 \mathrm{ml}$ were incubated at room temperature of $25-28^{\circ} \mathrm{C}$. Values are means $\pm \mathrm{SEM}, \mathrm{n}=4$. Significance of mean difference in percentage from control value: ${ }^{*} \mathrm{p}<0.01,{ }^{* *} \mathrm{p}<$ $0.005,{ }^{* *} \mathrm{p}<0.001$. Substrate as chromogenic hydrogen donor detected at $460 \mathrm{~nm}$ was $o$-dianisidine at $9 \mathrm{mg} / \mathrm{dl}$ in buffered saline of $140 \mathrm{mM} \mathrm{NaCl}, \mathrm{Na}_{2} \mathrm{HPO}_{4}-\mathrm{KH}_{2} \mathrm{PO}_{4}$ of $3.0 \mathrm{~mm}$, pH 7.4.

Allantoin, at the same micromolar concentration that was used at the higher urate level of $357 \mu \mathrm{M}$ listed in table 1 , failed completely to inhibit the substrate oxidations. This was with use of the same concentrations of iron sulfate and hydrogen peroxide. Similarly, $30 \mu \mathrm{M}$ levels of
Table 3. Ascorbic acid inhibition at concentration of $1.6 \mathrm{mg} / \mathrm{dl}$ (89 $\mu \mathrm{M})$ of substrate oxidation induced by micromolar reaction of ferrous sulfate $(9.8 \mu \mathrm{M})$ with hydrogen peroxide at $20 \mu \mathrm{M}$

\begin{tabular}{|c|c|c|c|}
\hline & $\begin{array}{l}\text { Time after } \\
\mathrm{H}_{2} \mathrm{O}_{2}\end{array}$ & $\begin{array}{l}\text { Absorbance in- } \\
\text { crease after } \mathrm{H}_{2} \mathrm{O}_{2}\end{array}$ & $\begin{array}{l}\% \\
\text { inhibition }\end{array}$ \\
\hline \multirow[t]{2}{*}{ Control } & $5 \mathrm{~min}$ & $0.039 \pm 0.007$ & \\
\hline & $10 \mathrm{~min}$ & $0.039 \pm 0.007$ & \\
\hline \multirow{2}{*}{$\begin{array}{l}\text { Ascorbate, } 1.6 \mathrm{mg} / \mathrm{dl} \\
\quad(89 \mu \mathrm{M})\end{array}$} & $5 \mathrm{~min}$ & $0.000 \pm 0.000$ & $100.0 \pm 0.0^{*}$ \\
\hline & $10 \mathrm{~min}$ & $0.000 \pm 0.000$ & $100.0 \pm 0.0^{*}$ \\
\hline
\end{tabular}

Mixtures of $5.085 \mathrm{ml}$ were incubated at room temperature of $25-28^{\circ} \mathrm{C}$. Values are means $\pm \mathrm{SEM}, \mathrm{n}=4$. Significance of mean difference in percentage from control value: ${ }^{*} \mathrm{p}<0.0001$. Substrate as chromogenic hydrogen donor detected at $460 \mathrm{~nm}$ was $o$-dianisidine at $9 \mathrm{mg} / \mathrm{dl}$ in buffered saline of $140 \mathrm{mM} \mathrm{NaCl}$, $\mathrm{Na}_{2} \mathrm{HPO}_{4}-\mathrm{KH}_{2} \mathrm{PO}_{4}$ of $3.0 \mathrm{mM}$, pH 7.4.

L-lysine and L-arginine, employed at concentrations close to the values found in human CSF $[16,17]$, also failed to inhibit the substrate oxidations (data not shown).

Table 2 lists data which demonstrate that free heme protein may be pro-oxidant at low concentration by reacting with a low concentration of hydrogen peroxide to cause oxidations. At a saline concentration of $12 \mathrm{mg} / \mathrm{dl}$, human hemoglobin reacted with a $20-\mu \mathrm{M}$ level of hydrogen peroxide to cause oxidation of dianisidine.

Oxidations became greater with interaction for $10 \mathrm{~min}$ compared to the absorbance increases from $5 \mathrm{~min}$ of interaction with the heme protein (see table 2).

Urate at $6.0 \mathrm{mg} / \mathrm{dl}(357 \mu \mathrm{M})$ inhibited the absorbance increases of dianisidine by a mean value of $90.6 \pm 0.90 \%$ $(\mathrm{p}<0.001)$ at $5 \mathrm{~min}$ of incubation with the peroxide. The color absorbances were greater at $10 \mathrm{~min}$ of reaction time with the hydrogen peroxide, with mean percentage inhibition of the oxidations by the urate averaging less at 80.3 $\pm 3.54 \%$. Apparently, the greater absorbance increases at $10 \mathrm{~min}$ resulted because more bivalent iron was freed in the hemoglobin by the action of hydrogen peroxide to cause more iron to be available to react by Fenton-type chemistry with the peroxide to oxidize more dianisidine. At 12 -fold lower urate concentration of $0.5 \mathrm{mg} / \mathrm{dl}(30 \mu \mathrm{M})$, uric acid inhibited the oxidations significantly less by percentage, both at 5 and $10 \mathrm{~min}$ of exposure to the hydrogen peroxide.

Table 3 lists the data which demonstrate that, at a level of $1.6 \mathrm{mg} / \mathrm{dl}(89 \mu \mathrm{M})$, ascorbic acid inhibited the oxidations to color substance by $100 \%$ when the dianisidine was oxidized by micromolar reaction of $9.8 \mu \mathrm{M}$ of ferrous 
Table 4. Ascorbic acid inhibition at concentration of $1.6 \mathrm{mg} / \mathrm{dl}$ (89 $\mu \mathrm{M})$ of substrate oxidation induced by reaction of human hemoglobin of $12 \mathrm{mg} / \mathrm{dl}$ with hydrogen peroxide at $20 \mu \mathrm{M}$

\begin{tabular}{lrlr}
\hline & $\begin{array}{c}\text { Time after } \\
\mathrm{H}_{2} \mathrm{O}_{2}\end{array}$ & $\begin{array}{l}\text { Absorbance in- } \\
\text { crease after } \mathrm{H}_{2} \mathrm{O}_{2}\end{array}$ & $\begin{array}{l}\% \\
\text { inhibition }\end{array}$ \\
\hline Control & $5 \mathrm{~min}$ & $0.050 \pm 0.028$ & \\
& $10 \mathrm{~min}$ & $0.094 \pm 0.006$ & \\
$\begin{array}{c}\text { Ascorbate, } 1.6 \mathrm{mg} / \mathrm{dl} \\
(89 \mu \mathrm{min})\end{array}$ & $0.000 \pm 0.000$ & $100.0 \pm 0.0^{*}$ \\
& $10 \mathrm{~min}$ & $0.001 \pm 0.008$ & $99.8 \pm 1.2^{*}$ \\
\hline
\end{tabular}

Mixtures of $5.060 \mathrm{ml}$ were incubated at room temperature of $25-28^{\circ} \mathrm{C}$. Values are means \pm SEM, $n=4$. Significance of mean difference in percentage from control value: ${ }^{*} p<0.0001$. Substrate as chromogenic hydrogen donor detected at $460 \mathrm{~nm}$ was $o$-dianisidine at $9 \mathrm{mg} / \mathrm{dl}$ in buffered saline of $140 \mathrm{mM} \mathrm{NaCl}$, $\mathrm{Na}_{2} \mathrm{HPO}_{4}-\mathrm{KH}_{2} \mathrm{PO}_{4}$ of $3.0 \mathrm{~mm}$, pH 7.4.

sulfate with $20 \mu \mathrm{M}$ of hydrogen peroxide at physiological $\mathrm{pH}$ of 7.4. No absorbance increases resulted after addition of hydrogen peroxide. The complete inhibition which was found at $5 \mathrm{~min}$ persisted over the next $5 \mathrm{~min}$ (and longer) of exposure to the peroxide at the employed antioxidant ascorbate level of $1.6 \mathrm{mg} / \mathrm{dl}(89 \mu \mathrm{M})$.

Table 4 shows that ascorbic acid at level of $1.6 \mathrm{mg} / \mathrm{dl}$ $(89 \mu \mathrm{M})$ also inhibited completely at $5 \mathrm{~min}$ the oxidations of dianisidine from the oxidant reaction of $12 \mathrm{mg} / \mathrm{dl}$ of hemoglobin in solution with $20 \mu \mathrm{M}$ of hydrogen peroxide. The inhibition remained virtually complete at $10 \mathrm{~min}$ of continued exposure to the hydrogen peroxide, in spite of much greater absorbance increases or oxidations in the control solutions from the continuing reaction of the hydrogen peroxide with the iron that resided in the hemoglobin (see table 4).

\section{Discussion}

The described experiments demonstrate that, at unprotected bivalent iron present at low level or at iron contained in heme protein like hemoglobin at quite low concentration, the iron can react with hydrogen peroxide at low level to produce oxidation of organic molecules very promptly. The demonstrated hemoglobin-hydrogen peroxide reactions confirm the finding of Gutteridge [18] who used concentrations quite higher of hemoglobin and hydrogen peroxide (e.g. 0.67 or $0.8 \mathrm{mM}$ of peroxide) with 2-hour incubations at $37^{\circ} \mathrm{C}$.
I postulate, after Goodman [7] and others [8,9], that the Fenton reaction involving iron is likely involved seminally in the early pathogenesis of $\mathrm{AD}[6]$ and also in lateonset MCI, after Markesbery and Lovell [5]. In many cases, the oxidative stress and cerebral injury probably begin a few decades earlier before the clinical manifestations of $\mathrm{AD}$ become obvious. Also, my in vitro experiments suggest that antioxidant protection by both sufficient ascorbic acid and uric acid may be effective to prevent Fenton reaction injury in these disorders. The results with these two hydrophilic antioxidants are also suggestive that both are essential in inducing the unusual long lifespan potential in humans among mammals [12-14].

Aerobic metabolic activity produces hydrogen peroxide by superoxide dismutases and select enzymes in many tissues; also by red blood cells which form this peroxide from its generated residual superoxide radical upon release of oxygen from its hemoglobin [19]. Cerebral metabolic activity is high in humans and catalase, an enzyme which converts hydrogen peroxide to water and ground state oxygen, is poor in the human brain [10]. It is relevant that hydrogen peroxide mean plasma levels of $34 \pm 18$ $\mu \mathrm{M}$ have been reported in healthy young adults and mean plasma levels of $38.3 \pm 6.2 \mu \mathrm{M}$ have been reported in adults with cardiac arrhythmias before cardioversion [20, 21]. Catalase is normally absent or extremely low in human plasma [10].

This investigation was conducted because: (1) ascorbic acid and uric acid are two major hydrophilic antioxidants in human plasma and many extracellular fluids and (2) iron toxicity in the human cortex may be an early and seminal event in the pathogenesis of $\mathrm{AD}$. The experiments used ascorbic acid and uric acid at concentrations readily attainable in human plasma by ingredient supplementation orally $[12,22,23]$. The experiments showed that ascorbic acid in the presence of bivalent iron is antioxidant, in contrast to being pro-oxidant [10]. In addition, it should be pointed out that 'free' iron in samples of CSF from a range of patients ranged from 3.5 to $24 \mu \mathrm{M}$ with a mean value of $9.4 \mu \mathrm{M}$ [24]. Also, one may note that the population study of Mikkelsen et al. [25] reported a mean serum uric acid value for males of $4.9 \mathrm{mg} / \mathrm{dl}$ with a standard deviation of $1.4 \mathrm{mg} / \mathrm{dl}$. The normal mean value for females is much lower. This fact suggests that the lower serum urate levels in females may be a cause for an apparent greater prevalence of $\mathrm{AD}$ in females for unknown reasons.

$\mathrm{AD}$ patients are reported to have lower plasma levels of uric acid, present more correctly as its monoanion urate $[26,27]$. Of significance, AD patients have an ab- 
normally increased renal fractional excretion of urate [26].

Both urate and ascorbate mean plasma levels are reported much lower in $\mathrm{AD}$ patients and in patients with $\mathrm{MCI}$, with mean values $<200 \mu \mathrm{M}(3.36 \mathrm{mg} / \mathrm{dl})$ for urate and $<26 \mu \mathrm{M}(0.46 \mathrm{mg} / \mathrm{dl})$ for ascorbate [28].

Healthy ascorbate values are considered to be in the vicinity of $54 \pm 37 \mu \mathrm{M}$ in plasma and in the vicinity of $133 \pm 59 \mu \mathrm{M}$ in CSF [29]. CSF urate mean value for elderly subjects was reported to be $5.52 \mu \mathrm{M}(0.09 \mathrm{mg} / \mathrm{dl})$, but significantly lower at $4.39 \mu \mathrm{M}(0.07 \mathrm{mg} / \mathrm{dl})$ in $10 \mathrm{pa}-$ tients with $\mathrm{AD}$-type dementia and their mean serum urate value was lower [30].

Ascorbic acid intakes $>95 \mathrm{mg} /$ day have been reported to have borderline significance of association with $\mathrm{AD}$ [31]. However, no study has yet been done apparently to determine if a combined supplemental intake of ascorbic acid and a precursor of uric acid like inosine or hypoxanthine $[23,32]$ may be effective in preventing the symptomatology of $\mathrm{AD}$ or late-onset MCI. The renal excretion of urate in man increases at plasma urate levels $>3-5 \mathrm{mg} /$ $\mathrm{dl}$ because of greater saturation of the tubular reabsorptive system for urate [33].

Higher urate plasma levels can be attained readily by daily inosine supplementation as shown by Spitsin et al. [23] during a trial in multiple sclerosis patients or by hypoxanthine, a more immediate metabolic precursor to uric acid. At $0.1 \mathrm{mmol} / \mathrm{kg}$ of body weight, hypoxanthine orally raised serum uric acid levels by $2.4 \pm 0.2 \mathrm{mg} / \mathrm{dl}$ (mean \pm SE) in normal adults [32]. In subjects with higher plasma uric acid levels in gout, CSF levels averaged as high as $1.79 \mathrm{mg} / \mathrm{dl}$ at average plasma level of $7.36 \mathrm{mg} / \mathrm{dl}$ [34].

CSF levels of urate in man are generally only about $6-15 \%$ of the concomitant usual plasma or serum urate levels of about 3-5 mg/dl [34]. Levels are attainable higher as measured in patients with gout [34]. Plasma ascorbic acid concentrations in the vicinity of $1.6 \mathrm{mg} / \mathrm{dl}(89 \mu \mathrm{M})$ as used in this in vitro investigation are readily attainable by employing less than megadoses of ascorbic acid daily [12]. In AD patients and in healthy subjects, plasma and CSF concentrations of ascorbic acid correlate highly and the levels also correlate with daily dosages of ascorbic acid [35]. The renal plasma level for substantial ascorbate excretion is generally $>1.0$ and $<2.0 \mathrm{mg} / \mathrm{dl}$ [33]. Combined supplementation with ascorbic acid may be warranted in a trial to render uric acid becoming innocuous biologically as an antioxidant, since ascorbate can scavenge and reduce urate anion free radical which forms in the potent antioxidant action of uric acid [36, 37]. Damage to enzymes by urate free radical in vitro can be prevented by conjoint use of ascorbate [36, 37]. Urate may act critically in the repair of oxidative damage to nucleobase in DNA [37]. Purines like uric acid are known to be essentially planar molecules which make them stack closely in the interior of double-stranded helixes of DNA [38].

\section{References}

1 Evans DA, Funkenstein HH, Albert MS, Scherr PA, Cook NR, Chown MJ, Hebert LE, Hennekens CH, Taylor JO: Prevalence of Alzheimer's disease in a community population of older persons higher than previously reported. JAMA 1989;262:2551-2556.

$\checkmark 2$ Brookmeyer R, Gray S, Kawa C: Projections of Alzheimer's disease in the United States and the public health impact of delaying disease onset. Am J Public Health 1998;88: 1337-1342.

$\checkmark 3$ Espeland MA, Henderson VW: Preventing cognitive decline in usual aging. Arch Intern Med 2006;166:2433-2434.

4 Nunomura A, Castellani RJ, Zhu X, Moreira PI, Perry G, Smith MA: Involvement of oxidative stress in Alzheimer disease. J Neuropath Exp Neurol 2006;65:631-641.

5 Markesbery WE, Lovell MA: Damage to lipids, proteins, DNA, and RNA in mild cognitive impairment. Arch Neurol 2007;64:954956.
6 Waugh WH: Cognitive decline therapy by iron burden reduction. Arch Intern Med 2007;167:1098.

7 Goodman L: Alzheimer's disease a clinicopathologic analysis of twenty-three cases with a theory on pathogenesis. J Nerv Mental Dis 1953;117:97-130.

-8 Connor JR, Snyder BS, Arosio P, Loeffler DA, LeWitt P: A quantitative analysis of isoferritins in select regions of aged, parkinsonian, and Alzheimer's diseased brains. J Neurochem 1995;65:717-724.

$\checkmark 9$ Todorich BM, Connor JR: Redox metals in Alzheimer's disease. Ann NY Acad Sci 2004; 1012:171-178.

10 Halliwell B: Oxidants and the central nervous system: some fundamental questions is oxidant damage relevant to Parkinson's disease, Alzheimer's disease, traumatic injury or stroke? Acta Neurol Scand 1989;126:23 33.
11 Hershey CO, Hershey LA, Varnes A, Vibhakar SD, Lavin P, Strain WH: Cerebrospinal fluid trace element content in dementia: clinical, radiologic, and pathologic correlations. Neurology 1983;33:1350-1353.

12 Ames BN, Cathcart R, Schwiers E, Hochstein P: Uric acid provides an antioxidant defense in humans against oxidant- and radicalcause aging and cancer: a hypothesis. Proc Natl Acad Sci USA 1981;78:6858-6862.

13 Cutler RG: Urate and ascorbate: their possible roles as antioxidants in determining longevity of mammalian species. Arch Gerontol Geriatr 1984;3:321-348.

14 Proctor P: Similar function of uric acid and ascorbate in man? Nature 1970;228:868.

15 Karlsson J: Antioxidants and Exercise. Champaign/IL, Human Kinetics, 1997, p 55.

16 Pomara N, Singh R, Deptula D, Chou JC-Y, Schwartz, LeWitt PA: Glutamate and other amino acids in Alzheimer's disease. Am J Psychiatry 1992;149:251-254. 
-17 Kuiper MA, Teerlink T, Visser JJ, Beergmans PL, Scheltens P, Wolters ECh: L-Glutamate, $\mathrm{L}$-arginine and L-citrulline levels in cerebrospinal fluid of Parkinson's disease, multiple system atrophy, and Alzheimer's disease patients. J Neural Transm 2000;107:183-189.

$>18$ Gutteridge JMC: Iron promoters of the Fenton reaction and lipid peroxidation can be released from haemoglobin by peroxides. FEBS Lett 1986;201:291-295.

-19 Waugh WH: Simplified method to assay total plasma peroxidase activity and ferriheme products in sickle cell anemia, with initial results in assessing clinical severity in a trial with citrulline therapy. J Pediatr Hematol Oncol 2003;25:831-834.

-20 Varma SD, Devamanoharan PS: Hydrogen peroxide in human blood. Free Radic Res Commun 1991;14:125-131.

-21 Smielecki J, Wykretowiez A, Mincykowski A, Kazmierczak M, Wysocki H: The influence of electrical cardioversion on superoxide anions $\left(\mathrm{O}_{2}^{-}\right)$production by polymorphonuclear neutrophils, hydrogen peroxide $\left(\mathrm{H}_{2} \mathrm{O}_{2}\right)$ plasma level and malondialdehyde serum concentration. Int J Cardiol 1996;56: 137-143.

-22 Pauling L: Are recommended daily allowances for vitamin $\mathrm{C}$ adequate? Proc Natl Acad Sci USA 1974;71:4442-4446.

-23 Spitsin S, Hooper DC, Leist T, Streletz LJ, Mikheeva T, Koprowski $\mathrm{H}$ : Inactivation of peroxynitrite in multiple sclerosis patients after oral administration of inosine may suggest possible approaches to therapy of the disease. Mult Scler 2001;7:313-319.
-24 Gutteridge JMC, Rowley DA, Halliwell B: Superoxide-dependent formation of hydroxyl radicals in the presence of iron salts. Biochem J 1981;199:263-265.

25 Mikkelson WM, Dodge HJ, Valkenburg, H: The distribution of serum uric acid values in a population unselected as to gout or hyperuricemia. Am J Med 1965;39:242-251.

26 Maesaka JK, Wolf-Klein G, Piccione JM, Ma CM: Hypouricemia, abnormal renal tubular transport, and plasma natriuretic factor(s) in patients with Alzheimer's disease. J Am Geriatr Soc 1993;41:501-506.

27 Rinaldi P, Polidori MC, Metastasio A, Mariani E, Mattioli P, Cherubini A, Catani M, Cecchetti R, Senin U, Mecocci P: Plasma antioxidants are similarly depleted in mild cognitive impairment and in Alzheimer's disease. Neurobiol Aging 2003;24:915-919.

28 Mecocci P, Polidori MC, Cherubini A, Ingegni T, Mattioli P, Catani M, Rinaldi P, Cecchetti R, Stahl W, Senin U, Beal MF: Lymphocyte oxidative DNA damage and plasma antioxidants in Alzheimer's disease. Arch Neurol 2002;59:794-798.

29 Tallaksen CM, Bøhmer T, Bell H: Concentrations of the water-soluble vitamins thiamin ascorbic acid, and folic acid in serum and cerebrospinal fluid of healthy individuals. Am J Clin Nutr 1992;56:559-564.

30 Tohgi H, Abe T, Takahashi S, Kikuchi T: The urate and xanthine concentrations in the cerebrospinal fluid in patients with vascular dementia of the Binswanger type, Alzheimer's-type dementia, and Parkinson's disease. J Neural Transm 1993;6:119-126.
1 Engelhart MJ, Geerlings MI, Ruitenberg A, van Swieten JC, Hofman A, Witteman JCM, Breteler MMB: Dietary intake of antioxidants and risk of Alzheimer disease. JAMA 2002;287:3223-3229.

32 Clifford AJ, Riumallo JA, Young VR, Scrimshaw NS: Effect of oral purines on serum and urinary uric acid of normal, hyperuricemic and gouty humans. J Nutr 1976;106:428450 .

33 Wesson LG: Physiology of the Human Kidney. New York, Grune \& Stratton, 1969, pp 182-186, 221.

34 Wolfson WQ, Levine R, Tinsley M, The transport and excretion of uric acid in man I. True uric acid in normal cerebrospinal fluid, in plasma, and in ultrafiltrates of plasma. J Clin Invest 1947;26:991-994.

35 Quinn J, Suh J, Moore MM, Kaye J, Frei B: Antioxidants in Alzheimer's disease-vitamin $\mathrm{C}$ delivery to a demanding brain. J Alzheimer's Dis 2003;5:309-313.

36 Maples KR, Mason RP: Free radical metabolite of uric acid. J Biol Chem 1988;263:17091712 .

37 Simic MG, Jovanovic SV: Antioxidation mechanisms of uric acid. J Am Chem Soc 1989;111:5778-5782.

38 Rodwell VW: Nucleotides; in Murray RK et al. (eds): Harper's Biochemistry, ed 24. Stamford, Appleton \& Lange, 1996, p 360. 